\title{
A09 オオクロバエの脂質代謝
}

○森林敦子 ${ }^{1}$, 倉橋弘 ${ }^{1}$, 内田桂吉 ${ }^{2}$, 杉江 $\vec{\tau}^{3}$, 片桐千仍 ${ }^{4}$ ( ${ }^{1}$ 国立感染症研究所 昆虫医科学部, ${ }^{2}$ 順天堂大学さ くらキャンパス生物学教室, 独立行政法人・農業環境技術研究所 昆虫エニット, ${ }^{4}$ 北海道大学低温科学研 究所 生化学部門)

Lipid metabolism of the blow fly, Calliphora nigribarbis (Diptera: Calliphogidae)

Moribayashi, A., Kurahashi, H., Uchida, K., Sugie, H., Katagiri, C.

オオクロバエは，短日低温下で世代交代を行う，冬期にあえて成虫が活動し産卵を行う特性を脂質の観点から検討 した．脂質の構成脂肪酸は，主にシス型のパルミトオレイン酸で， $40 \%$ から $50 \%$ を占めた．融点は， $\pm 0.5^{\circ} \mathrm{C}$ と低く 低温下でも液状であることから睘境に適応していると考えられる．この脂肪酸の合成がどのようにしてなされるか を検討するためにラベルのパルミチン酸，オレイン酸を使用し成虫羽化7日後のオス成虫に注入し，1日後，2日後の ラベル化合物の動向をカススマス，ガスクロ，高速液クロ，薄首クロマト等を用いて検討した．その結果ラベル化合物 は，主にそのままの形でジグリセロールやリン脂質に取りこまれていた，他の脂肪酸に代謝されることがほとんどな かったことからパルミトオレイン酸は，パルミチン酸や，オレイン酸を経由せず他の合成で作られると考えられる.

\section{A10 アカイエカの滤胞退化とアポトーシス}

○内田桂吉 ${ }^{1}$, 大森大二郎 ${ }^{1}$, 江下優樹 ${ }^{2}$, 福永昭廣 ${ }^{3}$ ( ${ }^{1}$ 順天堂大学, ${ }^{2}$ 大分医科大学感染分子病態制御講座, 3大阪市立大学看護短期大学部)

Apoptosis in degenerating ovarian follicles in mosquito Culex pipiens pallens

Uchida, K., Ohmori, D., Eshita, Y., Fukunaga, A.

我々はこれまで, 吸血したアカイエカの発育卵巣内で一部の滤胞が退化する滤胞退化の現象について調べ，退化滤 胞内ではカテプシンが活性化されていることを報告した，今回はさらに，この退化滤胞の滤胞上皮細胞で, アポトー シスが起こっていることを報告する，吸血後 2 日および 3 日の卵巣を取り出し，まず活性カスパーゼを営光基質を用 いて調べたところ, 退化濾胞のみに蛍光が見られ, さらにこれを共焦点顕微鏡で観察すると, 蛍光が演胞上皮細胞が 存在すると思われる退化滤胞の表面首に局在していることが確認された. つぎにTUNEL法で発育卵巣を処理・観察 してみると，退化末期と思われる凝縮した濾胞に虽光が見られた. 正常に発育を行っている渚胞では活性カスパーゼ あるいはTUNEL法のいずれでも営光は認められなかった。これらの結果から，退化滤胞では上皮細胞が最後まで退 化の過程をコントロールし，最後に自身がアポトーシスによって消隇していくと考えられる. 